Sri Lanka J. Aquat. Sci. 20 (2) (2015): 59-74

\title{
Community structure of zooplankton and trophic status of some inland reservoirs in the low country intermediate zone of Sri Lanka
}

\author{
S.M.A.I. Sangakkara and M.J.S. Wijeyaratne* \\ Department of Zoology and Environmental Management, University of \\ Kelaniya, Kelaniya, Sri Lanka \\ *Corresponding author: e-mail- zoomjs@kln.ac.lk
}

\begin{abstract}
Diversity and abundance of zooplankton in relation to nitrate- $\mathrm{N}$ and total phosphorus levels of 20 minor and medium scale reservoirs in the low country intermediate zone of Sri Lanka were studied in June-October 2013. Total phosphorus content ranged from $0.029 \mathrm{mg} \mathrm{L}^{-1}$ recorded in Wendaruwewa reservoir to $0.529 \mathrm{mg} \mathrm{L}^{-1}$ recorded in Karangamuwa reservoir and Nitrate- $\mathrm{N}$ content varied from $1.186 \mathrm{mg} \mathrm{L}^{-1}$ recorded in Adukkane reservoir to $5.625 \mathrm{mg} \mathrm{L}^{-1}$ recorded in Anukkane reservoir indicating that all reservoirs studied are eutrophic. During the present study, a total of 43 species of zooplankton, comprising 31 species of rotifers, 9 species of cladocerans and 3 species of copepods were recorded. Number of zooplankton species in any one reservoir, which ranged from 4 to 13 , was significantly correlated with the nitrate-N content $(\mathrm{p}<0.05)$. The most widely distributed zooplankton species was Diacyclops nanus, which was present in 15 reservoirs. Abundance of zooplankton ranged from 4 individuals $\mathrm{L}^{-1}$ recorded for Alona monocantha and Chydorus parvus in Wendaruwewa and Metiyagane reservoirs respectively to 1017 individuals $\mathrm{L}^{-1}$ recorded for Filinia terminalis in Galewela reservoir. Margalef index which ranged from 0.532 in Adukkane reservoir to 2.096 in Dewahuwa reservoir, was significantly correlated with nitrate-N content of water $(\mathrm{p}<0.05)$. Pielou index ranging from 0.65 in Galewela reservoir to 0.92 in Polpitiya reservoir and Shannon-Weiner index ranging from 0.91 in Munamaldeniya reservoir to 2.13 in Dewahuwa reservoir were not significantly correlated with nitrate-N and total phosphorus levels of water $(\mathrm{p}>0.05)$. Keratella quadrata was present only in Anukkane reservoir where the nitrate-N content was the highest and therefore it may be considered as a bio-indicator of high levels of nitrate-N. Eutrophic conditions of theses reservoirs may possibly be due to runoff of nutrients from agricultural fields as these are located in an intense agricultural area. Therefore, it is necessary to take immediate action to control the overuse of inorganic fertilizer in this area so that contamination of water bodies with nutrients can be minimized.
\end{abstract}

Keywords: Eutrophication, zooplankton, inland reservoirs, nutrients, bio-indicators 


\section{Introduction}

Zooplankton have been identified as one of the faunal groups highly sensitive to physicochemical conditions of water bodies (Marneffe et al. 1998). Being an important link between primary producers and secondary consumers, zooplankton play an important role in aquatic ecosystems (James 1991). Hence a change in the zooplankton community will affect the entire ecosystem.

Several studies on the zooplankton of Sri Lankan waters have been carried out. Taxonomy of Sri Lankan zooplankton has been studied by Changalath et al. (1974), Fernando (1980a, 1980b), Rajapakse and Fernando (1982) and Fernando and Weerawardhena (2002). Several studies on the zooplankton of Parakrama Samudra, an ancient major irrigation reservoir in the dry zone of Sri Lanka have received the attention of many researchers (Duncan 1983, 1984; Duncan and Gulati 1983, Fernando and Rajapakse 1983). The effects of food and temperature on the life cycle of some zooplankton in Kalawewa, another ancient major irrigation reservoir in the dry zone of Sri Lanka have been studied by Jayatunga (1986). Studies on the composition, distribution and population dynamics of zooplankton in several other water bodies in Sri Lanka including Beira lake (Mendis 1964, Costa and De Silva 1978, Nahallage and Piyasiri 1997, Kamaladasa and Jayatunga 2007), Giritale reservoir (Cooray and Jayatunga 2000), Bolgoda lake (Wignarajah and Amarasiriwardene, 1983), Kotmale reservoir (Chandrananda and Piyasiri 1992, Piyasiri and Chandrananda1998), Victoria reservoir (Piyasiri and Jayakody 1991, Fernando and Piyasiri 1994, Ariyaratne and Amarasinghe 2001), Randenigala reservoir (Pathmalal and Piyasiri 1999), Minneriya and Udawalawa reservoirs (Ariyaratne and Amarasinghe 2001), and Rantambe reservoir (Hettiarachchi and Piyasiri 1994) have also been carried out.

Although many studies have been carried out in other regions of the world to identify the zooplankton species which can be considered as bio-indicators of environmental conditions (Sládecek 1983; Matveeva 1991; Sampaio 2002), such studies in Sri Lanka are sparse. Silva et al. (2003) have studied the seasonal abundance of some zooplankton in relation to limnological characters in Kandy Lake, an urban reservoir in the central highlands of Sri Lanka. Abundance of zooplankton in Madu Ganga estuary, one of the Ramsar sites in Sri Lanka had been studied in relation to water quality parameters by Jayasiri (2007). Kamaladasa and Jayatunga (2007) have compared the composition, density and distribution of zooplankton in the restored and non-restored sections of Beira Lake, an urban reservoir in the metropolitan area of the city of Colombo while Wickramasinghe et al. (2012) have studied the zooplankton composition in Kotte-Kolonnawa wetland, which is also located in an urban area close to city of Colombo. Impact of $\mathrm{BOD}_{5}$ on zooplankton in some tanks in the northern region of Sri Lanka has also been studied (Patrick et al. 2012). No studies have been carried out so far in Sri Lanka on the diversity and abundance of zooplankton in relation to nitrate and total phosphorus contents in water.

Due to ancient hydraulic civilization, there is a large number of inland reservoirs in Sri Lanka. The water collected in these reservoirs is used for agricultural purposes, particularly for paddy cultivation during the non-rainy months. These 
reservoirs are located in a cascading system so that the water is used for agricultural activities to the maximum possible extent (Fernando and De Silva 1984). Sri Lanka is one of the countries with very high usage of fertilizer (IndexMundi 2015). Hence, there is a possibility of eutrophication of these reservoirs as a result of surface runoff of nutrients from agricultural fields. Although zooplankton is a group of organisms that are highly sensitive to water quality (Kumari et al. 2007), no studies have so far been carried out on zooplankton communities in the water bodies in the low country intermediate zone of Sri Lanka in relation to water quality parameters that are responsible for trophic status. The present study was therefore carried out to investigate the diversity and abundance of zooplankton in several closely situated inland reservoirs in an intense agricultural area of the low country intermediate zone of Sri Lanka in relation to nitrate-N and total phosphorus levels.

\section{Materials and Methods}

Twenty reservoirs located in the low country intermediate zone of Sri Lanka (Elevation: <100 m msl; annual rainfall: 1750-2500 mm) between latitudes $7^{\circ} 20^{\prime}$ $7^{\circ} 50^{\prime} \mathrm{N}$ and longitudes $80^{\circ} 00^{\prime}-80^{\circ} 40^{\prime} \mathrm{E}$ were used in this study (Fig. 1). Zooplankton were collected using a Patalas-Schindler sampler of $10 \mathrm{~L}$ capacity from June to October 2013. Zooplankton samples were immediately preserved at the sampling site using the method described by Dhargalkar and Verlecar (2004) and transported to the laboratory for further analysis. Zooplankton species were identified using Fernando (1990), Alekseev (2002), Korinek (2002), Kutikova (2002) and Fernando and Weerawardhena (2002). Abundance of each zooplankton species was determined by counting the number of individuals in each sample under an optical microscope using a Sedgewick rafter cell and then converting to the number $\mathrm{L}^{-1}$ in reservoir water.

Water samples collected in $100 \mathrm{ml}$ dark plastic bottles at the time of sampling of zooplankton were immediately preserved by adding $0.5 \mathrm{ml}$ of concentrated sulphuric acid and the nitrate-N and total phosphorus levels were subsequently determined using the methods described by APHA (1998).

For each reservoir, species richness of zooplankton was determined using Margalef index and the evenness was determined using the Pielou index. The diversity of zooplankton was determined using the Shannon-Weiner index.

Statistical analysis was carried out using MINITAB version 14.0.

\section{Results}

Nitrate-N and total phosphorus contents in the reservoirs studied varied in a wide range (Table 1). The lowest nitrate- $\mathrm{N}$ content, which was $1.186 \mathrm{mg} \mathrm{L}^{-1}$ was recorded in Adukkane reservoir while the highest value of $5.624 \mathrm{mg} \mathrm{L}^{-1}$ was recorded in Anukkane reservoir. The lowest total phosphorus level of $0.029 \mathrm{mg} \mathrm{L}^{-1}$ was recorded in Wendaruwewa reservoir while the highest value of $0.529 \mathrm{mg} \mathrm{L}^{-1}$ was recorded in Karangamuwa reservoir (Table 1). 


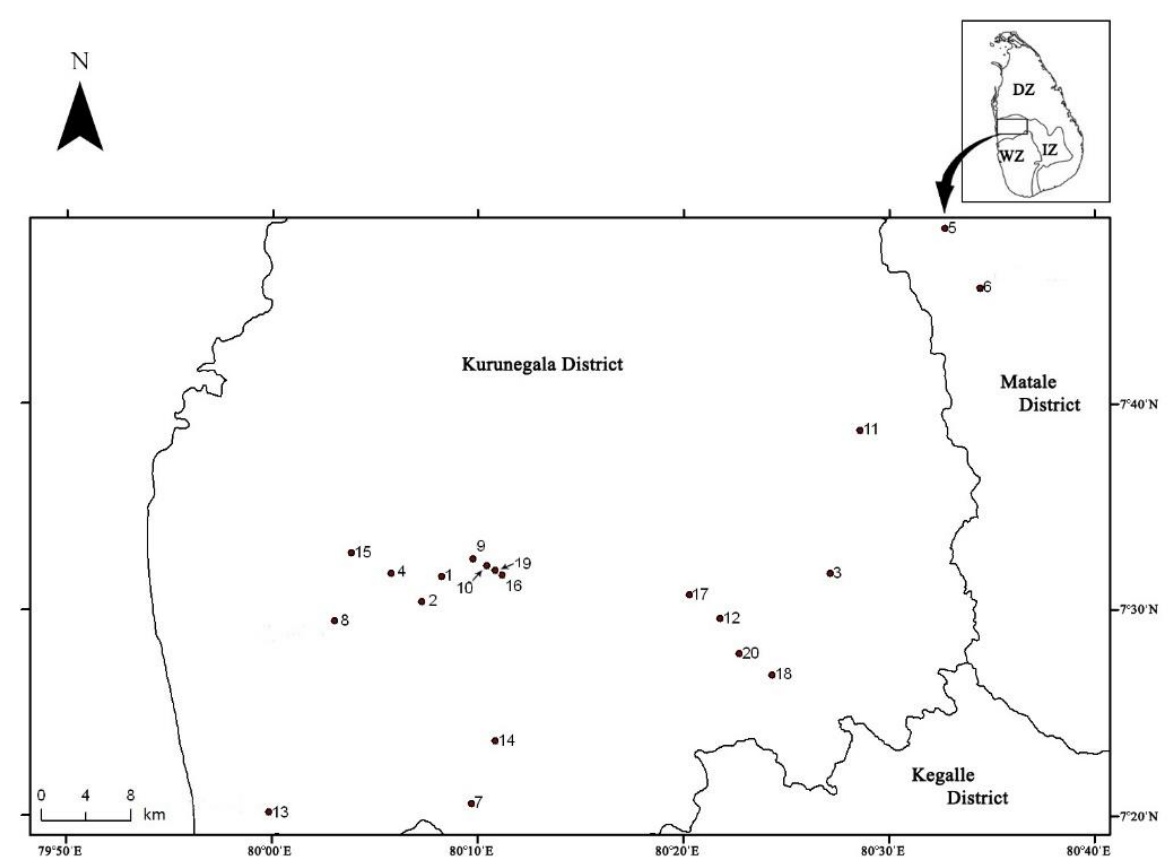

Figure 1. Location of the reservoirs studied. (WZ = Wet zone; IZ = Intermediate zone; DZ = Dry zone; The names of the reservoirs indicated by numbers are given in Table 1.

The total number of species of zooplankton recorded during the present study was 43 (Table 2). These included 3 species of copepods, 9 species of cladocerans and 31 species of rotifers. The number of species in any one reservoir ranged from 4 to 13. The lowest number of zooplankton species was recorded in 6 reservoirs (Adukkane, Anukkane, Makandura, Munamaldeniya, Polpitiya and Tampana) while the highest number was recorded in Galewela reservoir (Table 3). Only 4 reservoirs recorded $\geq 10$ species of zooplankton. The most widely distributed zooplankton species was the copepod Diacyclops nanus (in 15 reservoirs) followed by another copepod Diaptomus nadus and rotifer Trichocerca cylindrica (in 10 reservoirs each). Eighteen species of zooplankton showed a narrow distribution being present only in one reservoir (Table 3). 
Table 1. Total phosphorus content (TP), nitrate-N content $\left(\mathrm{NO}_{3}^{-}\right)$, number of species (S) and abundance of zooplankton, Margalef index $\left(\mathrm{D}_{\mathrm{Mg}}\right)$, Pielou index $\left(\mathrm{J}^{\prime}\right)$ and Shannon-Weiner index $\left(\mathrm{H}^{\prime}\right)$ of the reservoirs studied.

\begin{tabular}{llrrrrrrr}
\hline No. & $\begin{array}{c}\text { Name of } \\
\text { reservoir }\end{array}$ & $\begin{array}{c}\mathrm{TP} \\
\left(\mathrm{mg} \mathrm{L}^{-1}\right)\end{array}$ & $\begin{array}{c}\mathrm{NO}^{-} \\
\left(\mathrm{mg} \mathrm{L}^{-1}\right)\end{array}$ & \multicolumn{2}{c}{$\begin{array}{c}\text { S } \\
\text { Abundance } \\
\left(\text { Nos L }^{-1}\right)\end{array}$} & D & J' & $\mathrm{H}^{\prime}$ \\
\hline 1 & Adukkane & 0.046 & 1.186 & 4 & 280 & 0.53 & 0.78 & 1.07 \\
2 & Anukkane & 0.086 & 5.624 & 4 & 121 & 0.63 & 0.69 & 0.96 \\
3 & Bathalagoda & 0.075 & 2.403 & 5 & 1551 & 0.54 & 0.86 & 1.38 \\
4 & Bodhimulla & 0.030 & 3.886 & 9 & 364 & 1.36 & 0.91 & 2.00 \\
5 & Devahuwa & 0.060 & 3.416 & 12 & 190 & 2.10 & 0.86 & 2.13 \\
6 & Galewela & 0.190 & 4.936 & 13 & 2417 & 1.54 & 0.65 & 1.68 \\
7 & Galpihilla & 0.042 & 2.548 & 6 & 374 & 0.84 & 0.67 & 1.21 \\
8 & Gaiyawa & 0.104 & 3.923 & 8 & 204 & 1.32 & 0.88 & 1.83 \\
9 & Kanogama & 0.071 & 2.626 & 7 & 505 & 0.96 & 0.78 & 1.52 \\
10 & Karangamuwa & 0.529 & 3.452 & 11 & 494 & 1.61 & 0.90 & 2.17 \\
11 & Kimbulwana & 0.147 & 4.213 & 7 & 357 & 1.02 & 0.89 & 1.74 \\
12 & Kurunegala & 0.164 & 2.620 & 6 & 444 & 0.82 & 0.76 & 1.37 \\
13 & Makandura & 0.063 & 1.570 & 4 & 188 & 0.57 & 0.92 & 1.28 \\
14 & Methiyagane & 0.065 & 4.574 & 10 & 256 & 1.62 & 0.86 & 1.99 \\
15 & Munamaldeniya & 0.068 & 4.213 & 4 & 171 & 0.58 & 0.66 & 0.91 \\
16 & Polpitiya & 0.309 & 2.294 & 5 & 347 & 0.68 & 0.93 & 1.49 \\
17 & Saragama & 0.038 & 3.344 & 6 & 741 & 0.76 & 0.79 & 1.41 \\
18 & Tampana & 0.046 & 1.932 & 4 & 276 & 0.53 & 0.84 & 1.17 \\
19 & Umangawa & 0.057 & 2.765 & 9 & 669 & 1.23 & 0.70 & 1.55 \\
20 & Wendaruwewa & 0.029 & 2.294 & 5 & 134 & 0.81 & 0.85 & 1.37 \\
\hline
\end{tabular}

Table 2. List of zooplankton species recorded in 20 reservoirs studied.

Copepods

Acanthocyclops vernalis

Diacyclops nanus

Diaptomus nadus

Cladocerans

Alona monocantha

Chrydorus eurynotus

Chydorus parvus

Diaphanosoma brachyurum

Diaphanosoma singhalense

Karualona karua

Leptodora kindti

Moinadaphnia macleayi

Pseudosida szalayi
Brachionus urceus

Coelopus tenuior

Eothinia elongata

Euchlanis dilatata

Filinia terminalis

Hexarthra mira

Kellicottia longispina

Keratella earlinae

Keratella lenzi

Keratella quadrata

Lecane curvicornis

Monostyla bulla

Polyarthra dolichoptera 
64

S.M.A.I. Sangakkara\& M.J.S. Wijeyaratne/Sri Lanka J. Aquat. Sci. 20 (2) (2015): 59-74

\author{
Rotifers \\ Asplanchna priodonta \\ Brachionus angularis \\ Brachionus budapestinensis \\ Brachionous caudatus \\ Brachionus donneri \\ Brachionous falcatus \\ Brachionous forficula \\ Brachionus patulus \\ Brachionus rubens
}

\author{
Polyarthra vulgaris \\ Rattulus tigris \\ Rotaria citrina \\ Testudinell elliptica \\ Testudinella patina \\ Trichocera cylindrica \\ Trichocera dixon-nuttali \\ Trichocerca similis \\ Trichotria pocillum
}

The highest abundance of zooplankton was recorded in Galewela reservoir (2417 individuals $\mathrm{L}^{-1}$ ) followed by Bathalagoda reservoir (1551 individuals $\mathrm{L}^{-1}$ ). All other reservoirs recorded less than 1000 individuals $\mathrm{L}^{-1}$. The lowest abundance was recorded in Anukkane reservoir (121 individuals $\mathrm{L}^{-1}$ ) (Table 3).

The highest abundance of copepods was recorded in Bathalagoda reservoir (622 individuals $\mathrm{L}^{-1}$ ) while the lowest abundance (excluding the reservoirs where copepods were absent) was recorded in Dewahuwa reservoir (15 individuals $\left.\mathrm{L}^{-1}\right)$. The highest abundance of cladocerans was also recorded in Bathalagoda reservoir (320 individuals $\mathrm{L}^{-1}$ ) and the lowest abundance (excluding the reservoirs where cladocerans were absent) was recorded in Metiyagane reservoir (4 individuals $\mathrm{L}^{-1}$ ). The abundance of rotifers ranged from 16 individuals $\mathrm{L}^{-1}$ recorded in Adukkane reservoir to 2187 individuals $\mathrm{L}^{-1}$ recorded in Galewela reservoir (Table 3). When all reservoirs were considered the most abundant zooplankton species was Diacyclops nanus and the least abundant species was the cladoceran Alona monocantha (Table 2). The most abundant zooplankton species when any one reservoir was considered was the rotifer Filinia terminalis (1017 individuals $\mathrm{L}^{-1}$ ) recorded in Galewela reservoir while the least abundant was the cladocerans Alona monocantha recorded in Metiyagane reservoir and Chydorus parvus recorded in Wendaruwewa reservoir (4 individuals $\mathrm{L}^{-1}$ ).

The relative densities of major taxa of zooplankton are shown in Fig. 2. Copepods were present in 18 reservoirs while cladocerans were present only in 12 reservoirs. Rotifers were recorded in all 20 reservoirs. Copepods showed the highest relative density in 9 reservoirs. In Adukkane, Anukkane and Munamaldeniya reservoirs they contributed for $>70 \%$ of the zooplankton community (Fig. 2). The highest relative density of cladocerans (21\%) was recorded in Bathalagoda reservoir followed by Adukkane reservoir (17\%). In all other reservoirs, their relative density was $\leq 5 \%$ of the zooplankton community. In 11 reservoirs, rotifers showed the highest elative density among zooplankton. In two reservoirs, namely Polpitiya and Tampana, they were the only zooplankton species recorded. In Kurunegala, Galewela and Dewahuwa reservoirs they contributed for $\geq 90 \%$ of the zooplankton community 
Table 3. Abundance of zooplankton in the 20 reservoirs of the present study (in numbers $\mathbf{1}^{\mathbf{- 1}}$ ). The names of the reservoirs indicated by numbers are given in Table 1 . Full scientific names of species are given in Table 2.

\begin{tabular}{|c|c|c|c|c|c|c|c|c|c|c|c|c|c|c|c|c|c|c|c|c|c|}
\hline Species & 1 & 2 & 3 & 4 & 5 & 6 & 7 & 8 & 9 & 10 & 11 & 12 & 13 & 14 & 15 & 16 & 17 & 18 & 19 & 20 & Total \\
\hline \multicolumn{22}{|l|}{ Copepods } \\
\hline A. vernalis & - & 83 & - & - & - & - & - & 18 & - & - & - & - & - & - & - & - & - & - & - & - & 101 \\
\hline D. nanus & 168 & & 622 & 112 & 15 & 215 & 237 & 60 & 222 & 94 & & 34 & & 34 & 119 & & 213 & & 376 & 56 & 2577 \\
\hline D. nadus & 48 & 13 & - & 35 & - & - & - & - & 128 & 94 & 69 & - & 55 & 81 & - & - & 249 & - & 46 & - & 818 \\
\hline \multicolumn{22}{|l|}{ Cladocerans } \\
\hline $\begin{array}{l}\text { A. mono- } \\
\text { cantha }\end{array}$ & - & - & - & - & - & - & - & - & - & - & - & - & - & 4 & - & - & - & - & - & - & 4 \\
\hline C. eurynotus & - & - & - & - & - & 13 & 19 & - & - & - & - & - & - & - & - & - & - & - & - & - & 32 \\
\hline C. parvus & 48 & - & - & - & - & - & - & - & - & 8 & - & - & - & - & 9 & - & - & - & - & 4 & 69 \\
\hline $\begin{array}{l}\text { D. brachy- } \\
\text { urum }\end{array}$ & - & - & - & - & 5 & - & - & 6 & 47 & - & - & - & - & - & - & - & - & - & - & - & 58 \\
\hline $\begin{array}{l}\text { D. singha- } \\
\text { lense }\end{array}$ & - & - & - & - & - & - & - & - & 20 & - & - & - & - & - & - & - & - & - & - & - & 20 \\
\hline K. karua & - & - & - & - & - & - & - & - & - & - & - & - & - & - & - & - & 29 & - & - & - & 29 \\
\hline L. kindti & - & - & 34 & - & - & - & - & - & - & - & - & - & - & - & - & - & - & - & - & - & 34 \\
\hline M. macleayi & - & - & - & - & - & - & - & 6 & - & - & - & - & - & - & - & - & - & - & - & - & 6 \\
\hline P. szalayi & - & - & 286 & - & - & - & - & - & - & - & - & - & - & - & - & - & - & - & - & - & 286 \\
\hline Rotifers & & & & & & & & & & & & & & & & & & & & & \\
\hline A. priodonta & - & - & - & - & - & - & - & 30 & - & - & - & - & - & - & - & - & - & - & - & - & 30 \\
\hline B. angularis & - & - & - & - & - & - & - & - & - & - & - & 246 & - & - & - & - & - & - & - & - & 246 \\
\hline $\begin{array}{l}\text { B. budapesti- } \\
\text { nensis }\end{array}$ & - & - & - & - & - & - & - & - & - & 31 & - & - & - & - & - & - & - & - & 18 & - & 49 \\
\hline B. caudatus & - & - & - & - & - & - & - & - & - & 24 & 117 & - & 47 & - & - & 53 & - & - & - & - & 814 \\
\hline B. donneri & - & - & - & - & - & - & - & - & - & - & - & - & - & - & - & - & - & 69 & - & - & 69 \\
\hline B. falcatus & - & - & 202 & - & - & - & - & - & - & 16 & - & - & - & - & - & - & - & - & - & 13 & 231 \\
\hline B. forficula & - & - & - & 21 & 8 & 34 & - & - & - & - & - & 34 & - & 13 & - & - & - & - & - & - & 110 \\
\hline B.patulus & - & 13 & - & 21 & - & - & - & - & - & - & - & - & - & - & - & - & - & - & 18 & - & 52 \\
\hline B. rubens & - & - & 403 & - & - & - & - & - & - & - & - & - & - & 9 & - & - & - & - & - & - & 412 \\
\hline B. urceus & - & - & - & - & 15 & 34 & - & - & - & - & - & - & - & - & - & - & - & - & - & - & 49 \\
\hline C. tenuior & - & - & - & - & - & - & - & - & - & - & - & - & - & - & - & - & 29 & 146 & - & - & 175 \\
\hline
\end{tabular}




\begin{tabular}{|c|c|c|c|c|c|c|c|c|c|c|c|c|c|c|c|c|c|c|c|c|c|}
\hline E. elongata & - & - & - & - & - & 13 & 47 & - & - & - & - & - & - & 43 & - & - & - & - & - & - & 103 \\
\hline E. dilatata & - & - & - & 35 & 13 & 13 & - & - & - & - & - & - & - & 26 & - & - & - & - & 46 & - & 133 \\
\hline F. terminalis & - & - & - & 63 & 65 & 1017 & - & - & 47 & 31 & 32 & - & - & - & - & 140 & - & - & 73 & - & 1468 \\
\hline H. mira & - & - & - & 21 & 8 & 27 & - & 48 & - & 94 & 16 & - & - & - & - & - & - & - & 37 & 35 & 286 \\
\hline K. longispina & - & - & - & - & - & 13 & - & - & - & - & - & - & - & - & - & - & - & - & - & - & 13 \\
\hline K. earlinae & - & - & - & - & 5 & - & - & - & - & - & - & - & 71 & - & - & - & - & - & - & - & 76 \\
\hline K. lenzi & - & - & - & - & - & - & 33 & - & - & - & - & - & - & - & - & - & - & - & - & - & 33 \\
\hline K. quadrata & - & 12 & - & - & - & - & - & - & - & - & - & - & - & - & - & - & - & - & - & - & 12 \\
\hline L. curvicornis & - & - & - & - & - & - & - & 18 & - & - & - & 27 & - & 26 & 17 & - & - & - & - & - & 88 \\
\hline M. bulla & - & - & - & 21 & 5 & - & - & - & - & 23 & - & - & - & - & - & - & 205 & 38 & 18 & - & 310 \\
\hline $\begin{array}{l}\text { P. dolichop- } \\
\text { tera }\end{array}$ & - & - & - & - & - & - & - & - & - & - & 21 & - & - & - & - & - & - & - & - & - & 21 \\
\hline P. vulgaris & - & - & - & 35 & 13 & 357 & - & - & - & 39 & - & - & - & - & - & 60 & - & - & 37 & - & 541 \\
\hline R. t igris & - & - & - & - & - & - & - & - & - & - & - & - & - & - & - & - & 15 & - & - & - & 15 \\
\hline$R$. citrina & - & - & - & - & - & - & - & - & 7 & - & - & - & - & - & - & - & - & - & - & - & 7 \\
\hline T. elliptica & - & - & - & - & - & - & - & - & - & - & - & - & - & - & - & - & - & 23 & - & - & 23 \\
\hline T. patina & 16 & - & - & - & - & 40 & - & - & - & - & - & - & - & - & - & - & - & - & - & - & 56 \\
\hline T. cylindrica & - & - & - & - & 12 & 94 & 28 & 18 & - & 39 & 32 & 27 & 15 & 9 & - & 53 & - & - & - & - & 327 \\
\hline $\begin{array}{l}\text { T. Dixon- } \\
\text { nuttali }\end{array}$ & - & - & - & - & - & - & - & - & 34 & - & - & - & - & - & - & - & - & - & - & - & 34 \\
\hline T. similis & - & - & - & - & - & - & - & - & - & - & - & - & - & - & 26 & - & - & - & - & - & 26 \\
\hline T. pocillum & - & - & - & - & - & - & 9 & - & - & - & 69 & - & - & - & - & - & - & - & - & - & 78 \\
\hline
\end{tabular}


The relative densities of major taxa of zooplankton are shown in Fig. 2. Copepods were present in 18 reservoirs while cladocerans were present only in 12 reservoirs. Rotifers were recorded in all 20 reservoirs. Copepods showed the highest relative density in 9 reservoirs. In Adukkane, Anukkane and Munamaldeniya reservoirs they contributed for $>70 \%$ of the zooplankton community (Fig. 2). The highest relative density of cladocerans $(21 \%)$ was recorded in Bathalagoda reservoir followed by Adukkane reservoir (17\%). In all other reservoirs, their relative density was $\leq 5 \%$ of the zooplankton community. In 11 reservoirs, rotifers showed the highest elative density among zooplankton. In two reservoirs, namely Polpitiya and Tampana, they were the only zooplankton species recorded. In Kurunegala, Galewela and Dewahuwa reservoirs they contributed for $\geq 90 \%$ of the zooplankton community (Fig. 2).

The highest values for Margalef and Shannon-Weiner indexes were recorded for Dewahuwa reservoir while the lowest values were recorded for Adukkane and Munamaldeniya reservoirs respectively. The highest and lowest values for Pielou index was recorded for Polpitiya and Galewela reservoirs respectively (Table 1).

Correlation coefficients of the total number of species, abundance, Margalef index, Pielou index and Shannon-Weiner index with nitrate-N and total phosphorus contents are given in Table 4. Only the correlation coefficients of the number of species and Margalef index with the nitrate-N content were statistically significant $(\mathrm{p}<0.05)$.

The rotifer Keratella quadrata was present only in Anukkane reservoir where the nitrate-N content was the highest.

Table 4. Correlation coefficients for total number of species, abundance, Margalef index, Pielou index and Shannon-Weiner index with the Nitrate-N and total phosphorus contents of water. Values that are significant are indicated by asterisk $(\mathrm{p}<0.05)$.

\begin{tabular}{llc}
\hline & $\begin{array}{l}\text { Total } \\
\text { Phosphorus } \\
\text { content }\end{array}$ & $\begin{array}{l}\text { Nitrate-N } \\
\text { content }\end{array}$ \\
\hline Number of species & 0.330 & $0.452^{*}$ \\
Total Abundance of zooplankton & 0.153 & 0.177 \\
Abundance of rotifers & 0.241 & 0.287 \\
Abundance of cladocerans & -0.109 & -0.221 \\
Abundance of copepods & -0.147 & -0.098 \\
Margalef Index & 0.261 & $0.446^{*}$ \\
Pielou Index & 0.259 & -0.270 \\
Shannon-Weiner Index & 0.393 & 0.277 \\
\hline
\end{tabular}




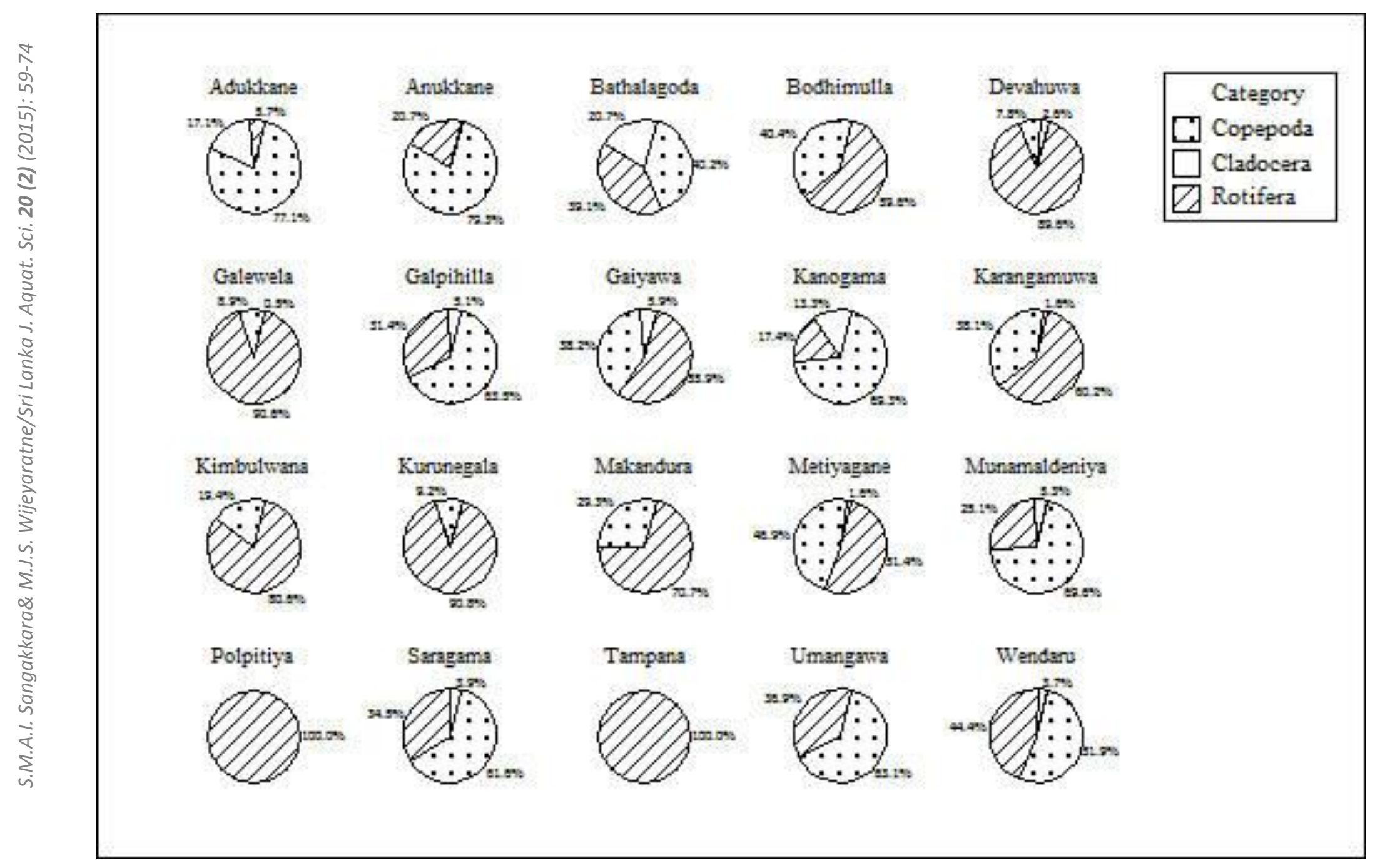




\section{Discussion}

Eutrophication has been identified as one of the main problems in water bodies as it disturbs the natural balance of aquatic ecosystems due to nutrient enrichment (Smith et al. 2006). Although Rott et al. (2008) have classified highland reservoirs, dry zone reservoirs and urban reservoirs in Sri Lanka as oligo-mesotrophic, meso-eutrophic and hyper-eutrophic respectively, trophic status of low country intermediate zone reservoirs has not been studied until the present study. Total phosphorus level is one of the parameters used to determine the trophic status of water bodies. According to the standards stipulated by USEPA (2000), total phosphorus levels in oligotrophic, mesotrophic and eutrophic water bodies are $<0.012,0.012-0.024$ and $>0.024 \mathrm{mg} \mathrm{L}^{-1}$ respectively. All the reservoirs of the present study have a total phosphorus level above $0.024 \mathrm{mg} \mathrm{L}^{-1}$ and therefore can be classified as eutrophic. This high level of total phosphorus may possibly be due to surface runoff from agricultural fields. Sri Lanka is one of the countries with very high consumption of fertilizer. Since 2002, average amount of fertilizer used in Sri Lanka had been $250-305 \mathrm{~kg} \mathrm{ha}^{-1}$ of arable land (IndexMundi 2015). Kurunegala district where 18 of the studied reservoirs are located is one of the districts in Sri Lanka with the highest extent of paddy lands cultivated (DCS 2015). The area where the other two reservoirs are located is also an area with large extent of paddy lands. Hence fertilizer usage in this region may also be very high resulting in excess nutrients being ultimately washed away into these reservoirs. However, the total phosphorus contents recorded in the present study are lower than those recorded in the Negombo estuary, which is a coastal water body receiving urban waste water runoff and effluents from shrimp farms (Gammanpila 2010).

In the present study, the highest number of species of zooplankton was recorded among rotifers followed by cladocerans and copepods respectively. Similar trend has been recorded in several other water bodies in Sri Lanka including Randenigala (Pathmalal and Piyasiri 1999) and Kotmale (Piyasiri and Chandrananda 1998) reservoirs in the central highlands, Bolgoda (Wignarajah and Amarasiriwardene 1983) and Beira (Kamaladasa and Jayatunga 2007) lakes in the western coastal region of the wet zone and Parakrama Samudra in the low country dry zone (Fernando and Rajapakse 1983). However, Wickramasinghe et al. (2012) recorded lesser number of species of cladocerans than that of copepods in an urban wetland in the wet zone of Sri Lanka. However, in their study too the highest number of species was recorded for rotifers.

The number of species of zooplankton recorded in a single reservoir during the present study was less than those recorded for many other reservoirs in Sri Lanka including Parakrama Samudra (Fernando and Rajapakse 1983), Kalawewa (Jayatunga 1986), Giritale (Cooray and Jayatunga 2000), Randenigala (Pathmalal and Piyasiri 1999), Kotmale (Piyasiri and Chandrananda), and Victoria (Piyasiri and Jayakody 1991) reservoirs. Of these, the latter three reservoirs are highland reservoirs which are classified as oligo-mesotrophic (Rott et al. 2008). The other three reservoirs are dry zone reservoirs which are classified as meso-eutrophic (Rott et al. 2008). According to Sampaio et al. (2002), many zooplankton species disappear with 
eutrophication mainly due to toxins produced by algal blooms especially by cyanobacteria blooms and also due to clogging of their filter feeding apparatus by algal cells. This may be the reason for the presence of lesser number of species of zooplankton in the reservoirs used for the present study, which are eutrophic. The number of species recorded in an eutrophic wetland (Wickramasinghe et al. 2012) and an eutrophic urban lake (Kamaladasa and Jayatunga 2007) in Sri Lanka are similar to those recorded in some reservoirs of the present study.

According to Sládecek (1983), the two rotifer species Brachionus angularis and $B$. falcatus are indicators of eutrophication. However, during the present study $B$. angularis was recorded only in one reservoir, namely Kurunegala and B. falcatus was recorded only in two reservoirs, namely Bathalagoda and Karangamuwa. Further, these two species have been recorded in Kotmale reservoir too (Piyasiri and Chandrananda 1998), which is classified as oligo-mesotrophic (Rott et al. 2008). In addition, B. falcatus has been recorded in Randenigala reservoir, (Pathmalal and Piyasiri 1999), which is another upland reservoir classified as oligo-mesotrophic (Rott et al. 2008) and in Parakrama Samudra (Fernando and Rajapakse 1983), which is considered as meso-eutrophic (Rott et al. 2008). Hence these two species are not confined to eutrophic water bodies they cannot be considered as bio-indicators of eutrophication in Sri Lankan waters. The rotifer species Brachionus caudatus, $B$. forficula and Trichocerca similis, which were recorded in the eutrophic reservoirs of the present study are also present in oligo-mesotrophic reservoirs. B caudatus has been recorded in Randenigala (Pathmalal and Piyasiri 1999) and Kotmale (Piyasiri and Chandrananda 1998) reservoirs while B. forficula and Trichocerca similis have been recorded in Kotmale reservoir (Piyasiri and Chandrananda 1998). Hence these three species also cannot be considered as bio-indicators of eutrophic conditions. All copepod and cladoceran species as well as the rotifer species other than the five species stated above have not been recorded from any oligo-mesotrophic reservoir in Sri Lanka. Hence those species may be considered as bio-indicators of eutrophic conditions. However, more research covering a large number of reservoirs is required in this regard.

Although total phosphorus content in the reservoirs studied varied from 0.029 $\mathrm{mg} \mathrm{L}^{-1}$ to $0.529 \mathrm{mg} \mathrm{L}^{-1}$, the abundance of any of the zooplankton species was not significantly correlated with the total phosphorus content $(p>0.05)$. Therefore, the abundance of the zooplankton species recorded during the present study cannot be considered as a parameter that indicates the level of total phosphorus and hence the degree of eutrophication of the inland reservoirs of the low country intermediate zone of Sri Lanka. Similarly the abundance of zooplankton species was also not correlated with the nitrate-N level. Hence it is not a parameter that indicates the level of nitrate$\mathrm{N}$ too. However, since the rotifer species Keratella quadrata was present only in Anukkane reservoir which had the highest nitrate-N content of $5.624 \mathrm{mg} \mathrm{L}^{-1}$ (Table 3 ), this species may be a bio-indicator of very high nitrate-N levels.

The number of species and the Margalef index, which is also a measure of species richness increased significantly with the nitrate- $\mathrm{N}$ content $(\mathrm{p}<0.05)$ although these were not significantly correlated with the total phosphorus content. The nitrate$\mathrm{N}$ content in these reservoirs may have increased due to nitrogen fixing cyanobacteria. However, more research on phytoplankton diversity is required in this 
regard. Since Pielou Index and Shannon-Weiner index did not show a significant correlation with the total phosphorus and nitrate-N contents in water, in eutrophic water bodies the evenness and diversity of zooplankton appear to be not correlated with these water quality parameters.

Since the eutrophic condition of these reservoirs had resulted possibly due to surface runoff from agricultural fields as they are located in an area of intense agricultural activities, it is necessary to take immediate action to control the overuse of inorganic fertilizer in this area in order to minimize the contamination of reservoirs with nutrients so that further eutrophication could be controlled.

\section{Acknowledgements}

Facilities provided by the University of Kelaniya for this research is gratefully acknowledged. Special thanks are due to Mr. R.P.K.C. Rajapakse of the Department of Zoology and Environmental Management of the University of Kelaniya for his assistance in preparing the manuscript.

\section{References}

Alekseev, V.R. 2002. Copepoda. 123-188 pp. In: A Guide to Tropical Freshwater Zooplankton (C.H. Fernando ed.), Backhuys Publishers, Leiden, The Netherlands.

APHA 1998. Standard Methods for Examination Water and Wastewater. American Public Health Association, Washington, DC, $20^{\text {th }}$ Edition. 1325 p.

Ariyaratne, M.G. \& P.B. Amarasinghe 2001. Seasonal variation in zooplankton abundance in relation to feeding of zooplanktivorous fish in three Sri Lankan reservoirs. In: Proceedings of the Seventh Annual Scientific Sessions of the Sri Lanka Association for Fisheries and Aquatic Resources (Abstracts). p. 15.

Chandrananda, W.P.N. \& S. Piyasiri 1992. Seasonal, diurnal and vertical distribution patterns of cyclapoids in Kotmale reservoir. Vidyodaya Journal of Science 4(1): 179-189.

Changalath, R., C.H. Fernando \& W. Koste 1974. Rotifers from Sri Lanka (Ceylon). New species and records with a list of Rotifera recorded and their distribution in different habitats from Sri Lanka. Bulletin of the Fisheries Research Station, Sri Lanka 25: 83-96.

Cooray, P.L.M. \& Y.N.A. Jayatunga 2000. Preliminary investigations on density, abundance and distribution of Zooplankton in Giritale Tank. Annual Research Sessions, University of Colombo, Colombo (Abstracts). p. 33.

Costa, H.H. \& S.S. De Silva (1978). The hydrobiology of Colombo (Beira) Lake III. Seasonal fluctuations of Plankton. Spolia Zeylanica 32: 35-53.

DCS 2015. Paddy Statistics. http://www.statistics.gov.lk/agriculture/Paddy\%20

Statistics/PaddyStats.htm (Accessed on 03.05.2015)

Dhargalka, V.K. \& X.N. Verlecar2004. Zooplankton Methodology. Collection \& Identification-A Field Manual. National Institute of Oceanography, Dona Paula, Goa. 16 p. 
Duncan, A. 1983. The composition, density and distribution of the zooplankton in Parakrama Samudra. 85-94 pp. In: Limnology of Parakrama Samudra, Sri Lanka (F. Schiemer ed.), Developments in Hydrobiology, Volume 12, W. Junk Publishers, The Hague, The Netherlands.

Duncan, A. 1984. Assessment of factors influencing the composition, body size and turnover rate of zooplankton in Parakrama Samudra, an irrigation reservoir in Sri Lanka. Hydrobiologia 113: 201-215.

Duncan, A. \& R.D. Gulati 1983. Feeding studies with natural food particles on tropical species of planktonic rotifers. $117-125$ pp. In: Limnology of Parakrama Samudra, Sri Lanka (F. Schiemer ed.), Developments in Hydrobiology, Volume 12, W. Junk Publishers, The Hague, The Netherlands.

Fernando, C.H. 1980a. The fresh water zooplankton of Sri Lanka with a discussion on tropical fresh water zooplankton composition. Internationale Revue der Gesamten Hydrobiologie 65: 85-125.

Fernando, C.H. 1980b. The species and size composition of tropical fresh water zooplankton with special reference to the oriental region (South East Asia). Internationale Revue der Gesamten Hydrobiologie 65: 411-426.

Fernando, C.H. \& R. Rajapakse 1983. Some remarks on long-term and seasonal changes in the zooplankton of Parakrama Samudra. 77-84 pp. In: Limnology of Parakrama Samudra, Sri Lanka (F. Schiemer ed.), Developments in Hydrobiology, Volume 12, W. Junk Publishers, The Hague, The Netherlands.

Fernando, C.H. \& S.S. De Silva 1984. Man-Made lakes: Ancient heritage and modern biological resources. 431-451 pp. In: Ecology and Biogeography in Sri Lanka (C.H. Fernando ed.), W. Junk Publishers, The Hague, The Netherlands.

Fernando C.H. \& S.R. Weerawardhena 2002. Sri Lankan Fresh Water Fauna and Fisheries: A Guide to the Fresh Water Fauna of Sri Lanka and a Genesis of the Fisheries, Volumes Publishing, Kitchener, Ontario, Canada. 634 p.

Fernando, Y.D.N. \& S. Piyasiri 1994. Composition and distribution of plankton and diurnal migratory patterns of zooplankton in Victoria reservoir, Sri Lanka. In: Proceedings of the $50^{\text {th }}$ Annual Sessions of Sri Lanka Association for the Advancement of Science, Part 1 (Abstracts). p. 172.

Gammanpila, M. 2010. Hydrography, nutrients and abundance and distribution of zooplankton in Negombo lagoon, Sri Lanka. Sri Lanka Journal of Aquatic Sciences 15: 13-24.

Hettiarachchi, H.A.A. \& S. Piyasiri 1994. The composition and population dynamics of plankton in the Rantambe reservoir, Sri Lanka. In: Proceedings of the $50^{\text {th }}$ Annual Sessions of Sri Lanka Association for the Advancement of Science, Part 1 (Abstracts). p. 173.

IndexMundi 2015. Sri Lanka-Fertilizer Consumption. http://www.indexmundi.com/ facts/sri-lanka/fertilizer-consumption (accessed on 04.05.2015)

James, M.R. 1991. Sampling and preservation methods for the quantitative enumeration of microzooplankton. New Zealand Journal of Marine and Fresh Water Research 25: 305-310. 
Jayasiri, H.B. 2007. Zooplankton abundance and seasonality in relation to some water quality parameters in Maduganga estuary, southwestern coast of Sri Lanka. In: Proceedings of the $13^{\text {th }}$ Annual Scientific sessions of Sri Lanka Association for Fisheries and Aquatic Resources (Abstracts). p. 7.

Jayatunga, Y.N.A. 1982. Studies on Hydrobiology and Zooplankton in the Kalawewa, $\mathrm{H}_{1}$ Area. M. Phil. Thesis, University of Colombo, Sri Lanka.

Jayatunga, Y.N.A. 1986. The influence of food and temperature on the life cycle characteristics of tropical cladoceran species from Kalawewa reservoir, Sri Lanka. PhD Thesis. University of London. 410 p.

Kamaladasa, A.I. \& Y.N.A. Jayatunga 2007. Composition, density and distribution of zooplankton in southwest and east lakes of Beira Lake soon after the restoration of south west lake. Ceylon Journal of Science (Bio Science) 36 (1): $1-7$.

Korinek, V. 2002. Cladocera. 69-122 pp. In: A Guide to Tropical Freshwater Zooplankton (C.H. Fernando ed.), Backhuys Publishers, Leiden, The Netherlands.

Kumari, P., S. Dhadse, P.R. Chaudhari \& S.R. Wate 2007. Bioindicators of pollution in lentic water bodies of Nagpur city. Journal of Environmental Science and Engineering 49(4): 317-324.

Kutikova, L.A. 2002. Rotifera. 23-68 pp. In: A Guide to Tropical Freshwater Zooplankton (C.H. Fernando ed.), Backhugs Publishers, Leiden.

Marneffe, Y., S. Comblin \& J. Thomé 1998. Ecological water quality assessment of the Bûtgenbachlake (Belgium) and its impact on the River Warche using rotifers as bioindicators. Hydrobiologia 387-388: 459-467.

Matveeva, L.K. 1991. Can pelagic rotifers be used as indicators of lake trophic state? Internationale Verenigung für Theoritische and Angenwandte Limnologie 24: 2761-2763.

Mendis, A.S. 1964. A contribution to the limnology of Colombo Lake. Bulletin of Fisheries Research Station Sri Lanka 17: 213- 220

Nahallage, C. \& S. Piyasiri 1997. Trophic status of Beira Lake. Vidyodaya Journal of Science 7: 33-42.

Pathmalal, M.M. \& S. Piyasiri 1999. Composition, distribution and density of zooplankton in Randenigala reservoir, Sri Lanka. Vidyodaya Journal of Science 8: 207-216.

Patrick, A.E.S., J.M. Kadotgasan \& G. Naveendrakumar 2012. Study to detect impacts of pollution on the distribution of zooplankton in the northern tropical ponds in Sri Lanka. Archives of Applied Science Research 4(6): 2552-2556.

Piyasiri, S. \& J.K.U. Jayakody 1991. Ecology of zooplankton in Victoria reservoir, Sri Lanka: I. Composition and population structure of zooplankton. Verhandlungen des Internationale Verein Limnologie 24: 1430-1435.

Piyasiri, S. \& W.P.N. Chandrananda 1998. Studies on the population structure of zooplankton in the Kotmale reservoir. Journal of the National Science Council of Sri Lanka 26 (2): 59-76.

Rajapakse, R. \& C. H. Fernando 1982. The Cladocera of Sri Lanka (Ceylon) with remarks of some species, Hydrobiologia 94: 49-69. 
Rott, E., E.I.L. Silva, E. Enriquez \& S. Ingthamjitr 2008. Phytoplankton communitystructure with special reference to species diversity in five tropical Asian water bodies. 81-120 pp. In: Aquatic Ecosystems and Development: Comparative Asian Perspectives - Biology of Inland Waters (F. Schiemer, D. Simon, U.S. Amarasinghe \& J. Moreau eds), Biology of Inland Waters, Margraf Publishers, Weikershim, Germany and Backhuys Publishers, Leiden, The Netherlands

Sampaio, E.V., O. Rocha, T. Matsumura-Tundisi \& J.G. Tundisi 2002. Composition and abundance of zooplankton in the limnetic zone of seven reservoirs of the Paranapanema River, Brazil. Brazilian Journal of Biology 62: 525-545.

Silva E.I.L., M. Ekanayaka \& K.M.B.C. Karunathilake 2003. Seasonal Abundance of Two Species of Rotifers (Brachionus calyciflorus and Keratella tropica) in Kandy Lake, a tropical urban water body in Sri Lanka. Sri Lanka Journal of Aquatic Sciences 8: 51-65.

Sládecek, V. 1983. Rotifers as indicators of water quality. Hydrobiologia 100: 169201.

Smith, V.H., S.B. Joye \& R.W. Howarth 2006. Eutrophication of freshwater and marine ecosystems. Limnology and Oceanography 51: 351-355.

USEPA 2000. Nutrient Criteria - Technical Guidance Manual: Lakes and Reservoirs. First Edition. United States Environmental Protection Agency, Washington, DC. $232 \mathrm{p}$.

Wickramasinghe, D.D., R. Abeygunawardena \& M. Hettiarachchi 2012. Community structure of zooplankton in two different habitats of Kotte-Kolonnawa wetland, Sri Lanka. International Journal of Environmental Sciences 3 (3): 965-975.

Wignarajah, S. \& P. Amarasiriwardene 1983. Some aspects of limnology of Bolgoda Lake II, Sri Lanka. 1. Composition and seasonal fluctuation of zooplankton. Journal of National Science Council of Sri Lanka 11(2): 255-268. 